\title{
Substantiation, Development and Implementation of Person-Centered Assessment of Psychosocial Significance of Chronic Dermatosis at the Stage of Primary Healthcare
}

\author{
Lidiya Cherkashyna
}

\begin{abstract}
High prevalence and incidence of chronic dermatoses among different age groups of Ukrainian population in combination with their multifactorial etiology and the progredient clinical course determine the need for the provision of general family medicine physicians with simple and accessible at the stage of primary healthcare technologies of medical care delivery to such patients. Patients with chronic dermatoses are known to be characterized by certain metabolic features, clinicopathologic cutaneous manifestations, as well as the development of special mental state associated with psychological trauma due to chronic dermatoses.

The objective of the research was to substantiate, develop and implement person-centered assessment of psychosocial significance of chronic dermatoses at the stage of primary healthcare delivery by general family medicine physicians.

Materials and methods. The study was carried out according to a specially developed program for collecting, accumulating and analyzing the results and included 114 patients with chronic dermatoses at the age of 29-58 years. Patients were divided into 2 groups: Group I included patients with chronic dermatosis duration of \&lt; 10 years and Group II comprised patients with chronic dermatosis duration of over 10 years. Medical and psychological examination of patients with chronic dermatoses was performed using the method of differentiated self-assessment of the functional state - the WAM (well-being, activity, mood), the Spielberger State Anxiety Scale modified by Khanin Yu.L., the personality questionnaire of the Bekhterev Institute (LOBI) etc.

Conclusions. The prognostic value of the decrease in strength and energy is an adverse effect on a relatively long clinical course of the disease. The diagnostic value of work/study limitations is 0.896 bit, and the prognostic value of this factor is a psychological limit of psychosocial functioning of an individual due to long-term clinical course of the disease. The presence of chronic skin disease was found to affect the patients\&rsquo; daily lives; taking (physical, aesthetic, intellectual, etc.). The diagnostic value of work/study limitations is 0.896 bit, and the prognostic value of this factor is a psychological limit of psychosocial functioning of an individual due to long-term clinical course of the disease. The presence of chronic skin disease was found to affect the patients\&rsquo; daily lives; taking (physical, aesthetic, intellectual, etc.). This indicated greater (p\&lt; 0.050) psychosocial limitation in individuals with long-term clinical course of chronic dermatoses being an indicator of the need for psycho-educational activities at the stages of clinical manifestations of chronic dermatoses.
\end{abstract}

\section{Keywords}

chronic dermatoses; psychosocial functioning of an individual; primary healthcare

Kharkiv Medical Academy of Post-Graduate Education of the Ministry of Health of Ukraine, Kharkiv, Ukraine

Corresponding author: narodmed@med.edu.ua

\section{Problem statement and analysis of the latest research}

High prevalence and incidence of chronic dermatoses (CD) among different age groups of Ukrainian population in combination with their multifactorial etiology and the progredient clinical course determine the need for the provision of general family medicine (GFM) physicians with simple and accessible at the stage of primary healthcare (PHC) technologies of medical care delivery to such patients $[4,5,14,15]$. Therefore, the scientific support for the community, family and patient's health preservation at the first medical contact in case of all kinds of illnesses and diseases, including $\mathrm{CD}$, is referred to the scientific specialty 14.01.38 - GFM [12]. Patients with $\mathrm{CD}$ are known to be characterized by certain metabolic features, clinicopathologic cutaneous manifestations, as well as the development of special mental state associated with psychological trauma due to CD [10]. Psychosocial symptoms among patients with $\mathrm{CD}$ are rather patient-specific [9], that determines the need for appropriate educational and behavioral programs at the stage of PHC [12]. At the current stage of GFM development, the problem of substantiating, developing 
and implementing person-centered assessment of psychosocial significance of $\mathrm{CD}$ at the stage of PHC remains unsolved, and there is a need for new developments [12, 14, 15], especially in the context of implementing educational and behavior modification (EBM) among patients with $\mathrm{CD}$.

The objective of the research was to substantiate, develop and implement person-centered assessment of psychosocial significance of CD at the stage of PHC delivery by GFM physicians.

\section{Materials and Methods}

The study was carried out according to a specially developed program for collecting, accumulating and analyzing the results and included 114 patients with CD at the age of 29-58 years. Medical and psychological examination of patients with CD was performed using the method of differentiated selfassessment of the functional state - the WAM (well-being, activity, mood) [1, 6], the Spielberger State Anxiety Scale modified by Khanin Yu.L. and the personality questionnaire of the Bekhterev Institute (LOBI) [1,6]. The psychosocial significance and impact of CD on patients\&rsquo; social functioning were determined using the results of self-assessment by the following factors: strength and energy $\left(\mathrm{F}_{22}\right)$, community $\left(\mathrm{F}_{25}\right)$ and family members' $\left(\mathrm{F}_{23}\right)$ attitude toward the patient $\left(\mathrm{F}_{23}\right)$, communication $\left(\mathrm{F}_{30}\right)$, limitation of pleasure $\left(\mathrm{F}_{24}\right)$, limitation of free time and other factors being psychosocially significant in everyday living $[2,9,12]$. An integral assessment and personal relevance of the factors included in the questionnaire are related to the concept of "quality of life" (QoL). We used the questionnaire that was developed, tested and validated in special research studies in case of different chronic somatic diseases [7, 8, 12]; we adapted it taking into account the fact that $\mathrm{CD}$ is considered as a manifestation of undifferentiated connective tissue dysplasia with a predominant skin lesion $[4,5]$. While analyzing the results, the following well-known and widely used clinical and statistical, clinical and information methods were used: anamnestic quantitative assessment, variational statistics, probability distribution of clinical signs with the assessment of the reliability of the results obtained $[2,13]$.

\section{Results and Discussion}

A significant decrease in strength and energy due to CD was noted in $(31.1 \pm 6.9) \%$ of patients of Group I with CD duration of $<10$ years and $(72.7 \pm 5.5) \%$ of patients of Group II with CD duration of over 10 years $(\mathrm{p}<0.001)$, that indicated that psychological discomfort and maladjustment were more expressed in patients of Group II (Table 2). The diagnostic value of this factor is $1.832 \mathrm{bit}$, and the prognostic value of the decrease in strength and energy is an adverse effect on a relatively long clinical course of the disease. Work and study limitations due to CD were observed in $(51.1 \pm 7.5) \%$ of patients of Group I and (80.3 \pm 4.9$) \%$ of patients of Group II $(\mathrm{p}<0.004)$, whereas the absence of such limitations was registered in $(20.0 \pm 6.0) \%$ and $(6.1 \pm 2.9) \%$ of patients, respectively $(\mathrm{p}<0.050) ;(28.9 \pm 6.8) \%$ of patients of Group I and (13.6 \pm 4.2$) \%$ of patients of Group II reported insignificant work/study limitations $(\mathrm{p}<0.050)$. The diagnostic value of work/study limitations is 0.896 bit, and the prognostic value of this factor is a psychological limit of psychosocial functioning of an individual due to long-term clinical course of the disease. The presence of chronic skin disease was found to affect the patients' daily lives; taking (physical, aesthetic, intellectual, etc.) pleasure was limited in (62.2 \pm 7.2$) \%$ of patients of Group I and (81.2 \pm 4.7$) \%$ of patients of Group II $(\mathrm{p}=0.025)$. Significant limitations of free time due to the need for treatment, self-care and health maintenance were registered in (62.2 \pm 7.2$) \%$ of patients of Group I and (59.4 \pm 5.9$)$ $\%$ of patients of Group II, $\mathrm{p}>0.05$.

It should be noted that most patients with $\mathrm{CD}(75.6 \pm 78.3 \%)$ had troubled relationships or limitations of communication with friends, co-workers, colleagues (Table 1). The level of this limitation was almost independent of the duration of CD clinical course. According to $(83.7 \pm 5.3) \%$ of patients of Group I and (73.9 \pm 5.3$) \%$ of patients of Group II suffering from CD, family members' attitude toward them changed significantly $(\mathrm{p}=0.211)$.

In addition, $(40.0 \pm 7.3) \%$ of patients of Group I and $(46.4 \pm 6.0) \%$ of patients of Group II reported significant material losses associated with their health conditions, while $(33.3 \pm 7.0) \%$ of patients of Group I and $(37.7 \pm 5.8) \%$ of patients of Group II reported moderate material losses that were independent of the duration of CD clinical course as well $(\mathrm{p}>0.05)$.

The integral indicator of psychosocial significance of CD was at the level of $(60.0 \pm 7.3) \%$ in Group I and (75.4 \pm 5.2$)$ $\%$ in Group II; when being converted to percent, the integral indicator of QoL associated with chronic skin disease was $(40.0 \pm 24.6) \%$, i.e. more than $60.0 \%$ of the patients' psychosocial functioning reduced.

This indicated greater $(\mathrm{p}<0.050)$ psychosocial limitation in individuals with long-term clinical course of CD being an indicator of the need for psychoeducational activities at the stages of clinical manifestations of CD $[9,10]$. The developed method is based on increasing the accuracy of assessing the level of CD patients' maladjustment considering the psychological indicators of social maladjustment being typical for such category of patients. To consider psychosocial limitations in an integrated manner and personify the monitoring, the indicator of psychosocial significance was used [9].

This diagnostic algorithm involves measuring the limitations of patient's basic activities, and qualitative and quantitative assessment of psychosocial significance of $\mathrm{CD}$ using the following formula $-\mathrm{PS}_{\mathrm{D}}=\mathrm{QHP}_{\mathrm{D}} / 5 \mathrm{~N}$, where $\mathrm{PS}_{\mathrm{D}}$ is the indicator of psychosocial significance of $\mathrm{CD}$ in a particular patient; $\mathrm{QHP}_{\mathrm{D}}$ is the sum of measurements concerning patient's basic activities; $\mathrm{N}$ is the number of measurements; 5 is a constant qualimetric coefficient. Psychosocial significance is low when $\mathrm{PS}_{\mathrm{D}}<0.30$; psychosocial significance is considered moderate 
Table 1. Factors of psychosocial functioning of patients with CD

\begin{tabular}{|c|c|c|c|c|c|c|c|c|c|c|}
\hline \multirow{3}{*}{$\rho$} & \multirow{3}{*}{\multicolumn{2}{|c|}{$\begin{array}{l}\text { Factors of psychosocial } \\
\text { functioning of an individual }\end{array}$}} & \multicolumn{4}{|c|}{ Patients with $\mathrm{CD}$, duration } & \multirow{3}{*}{$\begin{array}{l}\mathrm{PC}, \\
\text { pat }\end{array}$} & \multirow{3}{*}{ I, bit } & \multirow{3}{*}{$\eta^{2}$} & \multirow{3}{*}{$\mathrm{p}=$} \\
\hline & & & \multicolumn{2}{|c|}{$\begin{array}{c}\text { CD duration of }<10 \\
\text { years }\end{array}$} & \multicolumn{2}{|c|}{$\begin{array}{c}\text { CD duration of }>10 \\
\text { years }\end{array}$} & & & & \\
\hline & & & abs. & $(\mathrm{P} \pm \mathrm{m}) \%$ & abs. & $(\mathrm{P} \pm \mathrm{m}) \%$ & & & & \\
\hline \multirow{5}{*}{1} & \multirow{5}{*}{$\begin{array}{l}\text { Strength and energy } \\
\quad\left(\mathrm{DS}_{22}=5\right)\end{array}$} & $\mathrm{DS} \leq 3$ & 14 & $31.1 \pm 6.9$ & 48 & $72.7 \pm 5.5$ & +4.7 & 0.767 & \multirow{5}{*}{18} & \multirow{5}{*}{0.001} \\
\hline & & $\mathrm{DS}=4$ & 28 & $62.2 \pm 7.2$ & 13 & $19.7 \pm 4.9$ & -4.9 & 1.062 & & \\
\hline & & $\mathrm{DS}=5$ & 3 & $6.7 \pm 3.7$ & 5 & $7.6 \pm 3.3$ & -0.5 & 0.003 & & \\
\hline & & total & 45 & 100.0 & 69 & 100.0 & - & 1.832 & & \\
\hline & & $\mathrm{DS} \leq 3$ & 23 & $51.1 \pm 7.5$ & 53 & $80.3 \pm 4.9$ & +3.0 & 0.286 & & \\
\hline \multirow{3}{*}{2} & \multirow{3}{*}{$\begin{array}{l}\text { Work/study limitations } \\
\quad\left(\mathrm{DS}_{27}=5\right)\end{array}$} & $\mathrm{DS}=4$ & 13 & $28.9 \pm 6.8$ & 9 & $13.6 \pm 4.2$ & -3.3 & 0.249 & \multirow{3}{*}{8} & \multirow{3}{*}{0.004} \\
\hline & & $\mathrm{DS}=5$ & 9 & $20.0 \pm 6.0$ & 4 & $6.1 \pm 2.9$ & -5.2 & 0.361 & & \\
\hline & & total & 45 & 100.0 & 69 & 100.0 & - & 0.896 & & \\
\hline \multirow{3}{*}{3} & \multirow{3}{*}{ Limitation of pleasure } & $\mathrm{DS} \leq 3$ & 28 & $62.2 \pm 7.2$ & 56 & $81.2 \pm 4.7$ & +2.1 & 0.109 & \multirow{3}{*}{4} & \multirow{3}{*}{0.025} \\
\hline & & $\mathrm{DS}=4$ & 17 & $37.8 \pm 7.2$ & 13 & $18.8 \pm 4.7$ & -3.0 & 0.286 & & \\
\hline & & total & 45 & 100.0 & 69 & 100.0 & - & 0.395 & & \\
\hline \multirow{4}{*}{4} & \multirow{4}{*}{$\begin{array}{l}\text { Limitation of } \\
\text { communication } \\
\left(\mathrm{DS}_{30}=5\right)\end{array}$} & $\mathrm{DS} \leq 3$ & 34 & $75.6 \pm 6.4$ & 54 & $78.3 \pm 5.0$ & +1.4 & 0.002 & & \\
\hline & & $\mathrm{DS}=4$ & 6 & $13.3 \pm 5.1$ & 8 & $11.6 \pm 3.9$ & -1.6 & 0.005 & & \\
\hline & & $\mathrm{DS}=5$ & 5 & $11.1 \pm 4.7$ & 7 & $10.1 \pm 3.6$ & -1.4 & 0.003 & 2 & 0.050 \\
\hline & & total & 45 & 100.0 & 69 & 100.0 & - & 0.010 & & \\
\hline & Relationships with & $\mathrm{DS} \leq 3$ & 39 & $86.7 \pm 5.1$ & 49 & $71.0 \pm 5.5$ & +1.9 & 0.068 & & \\
\hline 5 & co-workers & $\mathrm{DS}=4$ & 6 & $13.3 \pm 5.1$ & 20 & $29.0 \pm 5.5$ & -3.4 & 0.264 & 2 & 0.050 \\
\hline & $\left(\mathrm{DS}_{25}=5\right)$ & total & 45 & 100.0 & 69 & 100.0 & - & 0.332 & & \\
\hline & & $\mathrm{DS} \leq 3$ & 28 & $62.2 \pm 7.2$ & 41 & $59.4 \pm 5.9$ & +0.9 & 0.011 & & \\
\hline & Limitation of free time & $\mathrm{DS}=4$ & 11 & $24.4 \pm 6.4$ & 18 & $26.1 \pm 5.3$ & -0.5 & 0.007 & & \\
\hline 6 & $\left(\mathrm{DS}_{26}=5\right)$ & $\mathrm{DS}=5$ & 6 & $13.3 \pm 5.1$ & 10 & $14.5 \pm 4.2$ & -0.4 & 0.004 & 2 & 0.043 \\
\hline & & total & 45 & 100.0 & 69 & 100.0 & - & 0.007 & & \\
\hline & & $\mathrm{DS} \leq 3$ & 29 & $64.4 \pm 7.1$ & 49 & $71.0 \pm 5.5$ & -0.4 & 0.014 & & \\
\hline & Feeling of inadequacy & $\mathrm{DS}=4$ & 11 & $24.4 \pm 6.4$ & 14 & $20.3 \pm 4.8$ & +0.8 & 0.017 & & \\
\hline 7 & $\left(\mathrm{DS}_{29}=5\right)$ & $\mathrm{DS}=5$ & 5 & $11.1 \pm 4.7$ & 6 & $8.7 \pm 3.4$ & +1.1 & 0.013 & 1 & 0.236 \\
\hline & & total & 45 & 100.0 & 69 & 100.0 & - & 0.044 & & \\
\hline & Family members' & $\mathrm{DS} \leq 3$ & 41 & $83.7 \pm 5.3$ & 51 & $73.9 \pm 5.3$ & +0.6 & 0.026 & & \\
\hline 8 & attitude toward & $\mathrm{DS}=4$ & 8 & $16.3 \pm 5.3$ & 18 & $26.1 \pm 5.3$ & -2.0 & 0.099 & 1 & 0.211 \\
\hline & the patient & total & 45 & 100.0 & 69 & 100.0 & - & 0.125 & & \\
\hline & Physical attractiveness & $\mathrm{DS} \leq 3$ & 31 & $68.9 \pm 6.9$ & 56 & $81.2 \pm 4.7$ & -0.7 & 0.044 & & \\
\hline 9 & $\left(\mathrm{DS}_{28}=5\right)$ & $\mathrm{DS}=4$ & 14 & $31.1 \pm 6.9$ & 13 & $28.8 \pm 4.7$ & +2.2 & 0.134 & 1 & 0.134 \\
\hline & & total & 45 & 100.0 & 69 & 100.0 & - & 0.178 & & \\
\hline & & $\mathrm{DS} \leq 3$ & 18 & $40.0 \pm 7.3$ & 32 & $46.4 \pm 6.0$ & -0.7 & 0.020 & & \\
\hline & & $\mathrm{DS}=4$ & 15 & $33.3 \pm 7.0$ & 26 & $37.7 \pm 5.8$ & -0.6 & 0.012 & & \\
\hline 10 & $\left(\mathrm{DS}_{33}=5\right)$ & $\mathrm{DS}=5$ & 12 & $26.7 \pm 6.6$ & 11 & $15.9 \pm 4.4$ & +2.3 & 0.120 & 0 & 0.384 \\
\hline & & total & 45 & 100.0 & 69 & 100.0 & - & 0.152 & & \\
\hline & & $\mathrm{DS} \leq 3$ & 27 & $60.0 \pm 7.3$ & 52 & $75.4 \pm 5.2$ & -1.0 & 0.076 & & \\
\hline & Overall index $\left(\mathrm{DS}_{33}=5\right)$ & $\mathrm{DS}=4$ & 18 & $40.0 \pm 7.3$ & 17 & $24.6 \pm 5.2$ & +2.1 & 0.162 & 3 & 0.050 \\
\hline & & total & 45 & 100.0 & 69 & 100.0 & - & 0.269 & & \\
\hline
\end{tabular}

Note. $(\mathrm{P} \pm \mathrm{m}) \%$ - specific gravity of patients; DS - diagnostic sum, $\mathrm{PC}$ - prognostic coefficient, I - information value of the factor (bit), $\eta^{2}-$ the influence of the factor on the difference in groups expressed in $(\%)$.

when $\mathrm{PS}_{\mathrm{D}}=0.3-0.69$; psychosocial significance is high when $\mathrm{PS}_{\mathrm{D}}>0.69$.

The increase in the accuracy of assessing the level of CD psychosocial significance is achieved through consideration of basic activities typical for this category of patients in an integrated manner. The differentiation of the indicator of psy- chosocial significance of dermatosis into three levels allows comparing the results with the results obtained in groups of dynamic observation and clinical monitoring being traditional for PHC system. This plays an important role in optimizing technologies of prevention and treatment at the stage of PHC. The use of the algorithm allows helping GFM physicians in 
the determination and individualization of treatment tactics using special tabular algorithm (Table 2).

Here is an example illustrating the method. A 48-year-old patient Viktor M. presented with psoriasis. According to the results of the questionnaire of differentiated self-assessment used during outpatient visit, the patient felt decreased strength and energy $(\mathrm{PC}=+4.7$ bit), some limitations while carrying out professional responsibilities $(\mathrm{PC}=+3.0 \mathrm{bit})$, limitation of pleasure $(\mathrm{PC}=+2.1$ bit) and communication with other people in everyday life; communication with co-workers was limited due to $\mathrm{CD}$ as well $(\mathrm{PC}=+1.9 \mathrm{bit})$.

Using the formula, we obtained the following results: $\mathrm{PS}_{\mathrm{D}}$ $=\mathrm{QHP}_{\mathrm{D}} / 5 \times \mathrm{N}=(+4.7+3.0+2.1+1.4+1.9-0.9) / 5 \times 6=12.2 / 30$ $=0.406$, which indicated high level of psychosocial significance of $\mathrm{CD}\left(\mathrm{PS}_{\mathrm{D}}>0.69\right.$; or $\left.\mathrm{PC}>+13.0\right)$. To simplify the calculation and visualization of the results, we present "Visual analogue scale for assessing personal result of the level of CD psychosocial significance" (Fig. 1).

\section{Conclusions}

The prognostic value of the decrease in strength and energy is an adverse effect on a relatively long clinical course of the disease. The diagnostic value of work/study limitations is 0.896 bit, and the prognostic value of this factor is a psychological limit of psychosocial functioning of an individual due to longterm clinical course of the disease. The presence of chronic skin disease was found to affect the patients' daily lives; taking (physical, aesthetic, intellectual, etc.). The diagnostic value of work/study limitations is $0.896 \mathrm{bit}$, and the prognostic value of this factor is a psychological limit of psychosocial functioning of an individual due to long-term clinical course of the disease. The presence of chronic skin disease was found to affect the patients' daily lives; taking (physical, aesthetic, intellectual, etc.). This indicated greater $(\mathrm{p}<0.050)$ psychosocial limitation in individuals with long-term clinical course of CD being an indicator of the need for psycho-educational activities at the stages of clinical manifestations of CD.

\section{Prospects for further research}

The assessment of the dynamics of CD psychosocial significance indicators under the influence of EBM at the stages of PHC is promising.

\section{References}

[1] Aleksandrovskiy YuA. Pogranichnyye psikhicheskiye rasstroystva. Moscow: Meditsina; c1993. 400p.

[2] Harnyk TP, Mykhailov BV, Cherkashyna LV et al. Otsinka rivnia somatohennoii astenizatsii pry khronichnykh zakhvoriuvanniakh ta dermatozakh riznoho henezu. Reiestr haluzevykh novovveden MOZ Ukraiiny. 2010. Vyp. 32-33. Haluzeve novovvedennia \#477/33/10.
[3] Gubler YeV. Informatika v patologiyi, klinicheskoy meditsine i pediatriyi. Leningrad: Meditsina; c1990. 176p.

[4] Mavrov II, Savenkova VV, Cherkashyna LV, Shkliar SP. Metodyka vyvchennia rehionalnoii poshyrenosti dermatoziv $\mathrm{z}$ urakhuvanniam faktoriv dovkillia. Reiestr haluzevykh novovveden MOZ ta AMN Ukraiiny, 2009. Vyp. 30-31. Haluzeve novovvedennia \#73/30/09.

[5] Mavrov II, Shkliar SP, Savenkova VV, Cherkashyna LV. Poshyrenist systemnykh zakhvoriuvan spoluchnoii tkanyny ( $\mathrm{z}$ perevazhnym urazhenniam shkiry) u Kharkivskomu rehioni zalezhno vid faktoriv dovkillia. Dermatolohiia ta venerolohiia. 2009;1:3-18.

[6] Mikhaylov BV, Serdyuk AI, Fedoseyev VA. Psikhoterapiya v obshchesomaticheskoy meditsine: Klinicheskoye rukovodstvo. Kharkov: Prapor; c2002. 128p.

[7] Naprieienko OK. Depresii ta tryvoha v zahalnomedychnii praktytsi (sotsialni, diahnostychni ta likuvalnoprofilaktychni aspekty). Visnyk psykhiatrii ta psykhofarmakoterapii. 2002;1:7-12.

[8] Panchenko MS. Psychopathological symptoms in different variants of nonpsychotic disorders in patients with high cardiovascular risk. Visnyk problem biolohii i medytsyny. 2014;4:(114):172-176. [published in Ukrainian]

[9] Cherkashyna LV. Sposib otsinky rivnia psykhosotsialnoii znachymosti dermatozu. Ukrainian patent UA 40546. 2009, April 10.

[10] Cherkashyna LV. Sposib otsinky rivnia psykhotravmatyzatsii khvorykh dermatozom. Ukrainian patent UA40547. 2009, April 10.

[11] Pro zatverdzhennia pasportu spetsialnosti 14.01.38 - zahalna praktyka-simeina medytsyna. The Order of the Cabinet of Ministers of Ukraine of 01.07.2010, No 53-09/5.

[12] Serdyuk AI, Mikhaylov BV, Korop AF, Chugunov VV. Metodika obyektivizatsiyi effektivnosti psikhoterapiyi somaticheskikh bolnykh: Metodicheskiye rekomendatsiyi. Kharkov; c1998. 28p.

[13] Moskalenko VM, Voronenko YuV. Sotsialna medytsyna ta orhanizatsiia okhorony zdorovia: manual. Moskalenko VM, Voronenko YuV, editors. Ternopil; 2002;50-75.

[14] Cherkashyna LV. Psykhohenni dermatozy: otsinka psykhosotsialnoii znachymosti na etapakh dermatolohichnoho monitorynhu. Zbirnyk naukovykh prats spivrobitnykiv NMAPO imeni P.L. Shupyka. 2012;21(4):122-130.

[15] Cherkashyna LV. Somatogenias among the patients of dermatological profile: innovative providing of diagnostic technologies. Probl. ekolohichnoii ta med. henetyky i klin. imunolohii: Zb. naukovykh prats. 2013;2(116):345-358. [published in Ukrainian] 
Table 2. Algorithm for screening assessment of CD psychosocial significance

\begin{tabular}{|c|c|c|c|c|}
\hline \multicolumn{4}{|c|}{ Criteria (signs) for screening and their gradation } & \multirow{2}{*}{$\mathrm{PC}$} \\
\hline \multicolumn{3}{|l|}{ Logic value of predictive sign } & Sign gradation & \\
\hline \multirow{2}{*}{\multicolumn{3}{|c|}{ Level of limitation of strength and energy due to $C D$}} & $\mathrm{DS} \leq 3$ & +4.7 \\
\hline & & & $\mathrm{DS}>3$ & -4.9 \\
\hline \multirow{2}{*}{\multicolumn{3}{|c|}{ Level of work limitation due to $\mathrm{CD}$}} & $3 \leq \mathrm{DS}$ & +3.0 \\
\hline & & & $\mathrm{DS}>3$ & -7.3 \\
\hline \multirow{2}{*}{\multicolumn{3}{|c|}{ Level of pleasure limitation due to $\mathrm{CD}$}} & $\mathrm{DS} \leq 3$ & +2.1 \\
\hline & & & $\mathrm{DS}>3$ & -3.0 \\
\hline \multirow{2}{*}{\multicolumn{3}{|c|}{ Level of communication limitation due to CD }} & $\mathrm{DS} \leq 3$ & +1.4 \\
\hline & & & $\mathrm{DS}>3$ & -1.6 \\
\hline \multirow{2}{*}{\multicolumn{3}{|c|}{ Level of limitation of communication with co-workers due to CD }} & $\mathrm{DS} \leq 3$ & +1.9 \\
\hline & & & $\mathrm{DS}>3$ & -3.4 \\
\hline \multirow{2}{*}{\multicolumn{3}{|c|}{ Level of free time limitation due to CD }} & $\mathrm{DS} \leq 3$ & +0.9 \\
\hline & & & $\mathrm{DS}>3$ & -0.9 \\
\hline \multicolumn{4}{|c|}{$\begin{array}{l}\text { Level of CD psychosocial significance } \\
\end{array}$} & \\
\hline \multirow{2}{*}{\multicolumn{2}{|c|}{\begin{tabular}{c|c|c} 
& \multicolumn{2}{c}{ Level of CD psychosocial sig } \\
$\begin{array}{c}\mathrm{PS}_{\min } \leq-13 \\
\text { minimal level of } \\
\text { psychosocial significance }\end{array}$ & $\begin{array}{c}\text { moderate level of } \\
\text { psychosocial } \\
\text { significance }\end{array}$
\end{tabular}}} & \multirow{2}{*}{\multicolumn{2}{|c|}{$\begin{array}{c}\mathrm{PS}_{\max } \geq+13 \\
\text { high level of } \\
\text { psychosocial significance }\end{array}$}} & \\
\hline & & & & \\
\hline
\end{tabular}

Figure 1. Visual analogue scale for assessing personal result of the level of $\mathrm{CD}$ psychosocial significance

Received: $2018-11-15$

Revised: 2018-11-26

Accepted: $2018-11-26$ 